\title{
Scientific Language, Journals and Careers
}

\author{
Lawrence T. Nichols ${ }^{1}$
}

Published online: 15 November 2016

(C) Springer Science+Business Media New York 2016

In this issue we present a diverse mix of papers that address both epistemology and professional practice. The epistemological questions deal mainly with the language of sociology as a field of organized learning or a social science. The professional issues concern the role and influence of academic journals, as well as personal career choices regarding how to do sociology, that is, how to translate the discipline into personal practice.

Two articles link to our most recent issue on the state of journals in sociology. Charles Crothers adds an international dimension to that discussion by delineating the role of the journal, New Zealand Sociology in creating a national sociology in his native land. Jennifer Platt, meanwhile, touches on the issue of the so-called "top three" US journals in the field during her discussion of the professional networks and publishing patterns of the twenty most recent presidents of the American Sociological Association. Platt's analysis engages issues raised by Stephen Turner in his recent book, American Sociology, especially alleged self-perpetuating elites that impact the production of knowledge and control important rewards within the discipline.

Monte Bute also deals with professional paths, in an autobiographical account of a highly unlikely career. Some readers will recall Jesse Wozniak's recent advocacy of "gonzo" sociology with its admonition of taking risks to produce knowledge and insight. Bute, however, goes further and, by his own admission seems to have often been poised on the edge of self-destruction. And yet he always prevailed and became more committed to a sociological vocation or lifestyle blending education, research and activism.

Christian Smith has made a major contribution to this issue through his work in organizing a mini-symposium on the concept of "culture" in contemporary sociology. The starting point of the conversation is his own critique of what he regards as the "inchoate" (or perhaps one might say "anomic") situation of cultural discourse. Four papers, by Lynn Spillman, Douglas Porpora, Andrea Voyer and Monika Krause

Lawrence T. Nichols

lnichol2@wvu.edu

1 Department of Sociology and Anthropology, West Virginia University, 307 Knapp Hall, PO Box 6326, Morgantown, WV 26506-6326, USA 
respond to Smith's argument, some mostly concurring and others taking a different stance. I am always pleased when we can bring out such symposia, as I was urged to do, years ago, by my first editorial "boss," Irving Louis Horowitz when Transaction Publishers produced this journal. And so a word of special thanks is due to all these participants.

The concept of culture has long been a matter of personal interest, and so, with apologies, I would like to offer a brief sketch of how the field has changed, re culture, since the time of my early training. As an undergraduate at Saint Louis University in the late 1960s, my mentor was Clement S. Mihanovich who professed a type of sociology rooted in the "formal" approach of Georg Simmel and Leopold von Wiese. At its core, for Mihanovich, sociology was the study of processes of association and dissociation, that is, as he put it, "why groups form and why groups break up"- - a distinctive task not performed by any other academic field. A la Simmel, for him interaction was "form" (e.g., the process of competition) and culture merely "content" (e.g., sports or politics).

Meanwhile, what Gary Alan Fine has termed the "second Chicago school" was also going strong, and I was exposed to some of its thinking on social psychology by department chair Thomas McPartland (of the "Iowa School" of symbolic interaction) and on deviance and social control by Steven Vago. This approach also had deep roots in "formal" sociology, as manifested in the early translations of Simmel by Albion Small, first editor of the American Journal of Sociology and, more famously, in the influential textbook, An Introduction to the Science of Sociology by Robert Park and Ernest Burgess. Edwin Sutherland's criminological theory of "differential association" (taught at Saint Louis by Dr. Marie Matthews) and Erving Goffman's "presentation of self in everyday life" can likewise be considered processes of sociation in Simmel's sense. However, the Chicago approach also arose out of American pragmatism and its focus on mind and behavior, most famously of course in George Herbert Mead's Mind, Self and Society and Herbert Blumer's "symbolic interaction" that emerged from it. This was accompanied by a focus on attitudes, especially as developed by W. I. Thomas from the time of his early interest in folk psychology and the allegedly universal "four wishes," and articulated as "values and attitudes" in the landmark Polish Peasant in Europe and America with Florian Znaniecki. In the 1928 book, The Child in America, Thomas and Dorothy Swaine Thomas presented the famous principle that if people define situations as real, they are real in their consequences. This became the basis of the "labeling" approach of the "second Chicago school" that I encountered, via Vago, in the works of Howard S. Becker, Edwin Lemert and Kai Erikson. The same themes pervaded the "constructionist" model of the mid to late 1970s, as articulated by Malcolm Spector and John Kitsuse, Joel Best, Joseph Gusfield, Donileen Loseke, Peter Ibarra and others. All of this I found very interesting, but, as can be seen, none of it was grounded in the idea of culture.

At the time of my socialization into the discipline, functional analysis or structuralfunctionalism remained influential, though its aura was fading. Indeed, this perspective was not really taught at Saint Louis University, and I would suggest that claims about its hegemony should be approached cautiously. Talcott Parsons at Harvard, and Robert $\mathrm{K}$. Merton at Columbia, were regarded as functionalism's major figures, and there was even a conflict variant, articulated by Lewis Coser who had trained at Columbia, and by Ralf Dahrendorf. Parsons, always interested in the division of labor among academic 
fields, located sociology within the realm of "the sciences of action" (following Max Weber's usage re "action" as meaningful behavior), all of which examined three interpenetrating systems of action. In this model, sociology focused on the social system, anthropology on the cultural system, and psychology on the personality system. So culture was present in the Parsonsian approach (which had roots in the anthropology of Bronislaw Malinowski, A. R. Radcliffe Brown, Margaret Mead and Ruth Benedict, as well as Clyde and Florence Kluckhohn's “culture and personality”), but it was subordinate to interaction in institutionalized roles - at least for sociologists.

I was not much exposed to conflict sociology during my undergraduate and M.A. studies, except in Mihanovich's graduate course on European social theorists. However, by the mid-1970s, when I moved to Boston College for doctoral work, the conflict perspective had become widely influential and was on its way to even greater dominance. At present, for practical purposes, the official stance of the American Sociological Association and its regional counterparts may arguably be described as democratic socialism, which tends to approach sociology as "the field of inequality studies." Decades ago, in the wake of the African-American civil rights movement, the antiVietnam War movement and race-based unrest and violence in US cities, sociologists began producing a conflict paradigm rooted largely in C. Wright Mills's "power elite" model and neo-Marxism. Jack Roach and others called for a "radical sociology," and a conflict-oriented journal, The Insurgent Sociologist was launched. Richard Quinney, Michael Burawoy and others published on capitalism and political economy and a new, "critical" criminology arose from the works of Ian Taylor, Paul Walton and Jock Young. Theda Scopol produced a Marxist-oriented theory of states and revolutions. There was also a renewed interest in the Frankfurt School of Theodor Adorno, Max Horkheimer and Herbert Marcuse that blended conflict theory with psychoanalysis, and later, via Jurgen Habermas, with communicative action. Meanwhile, Paolo Frere's Pedagogy of the Oppressed also became popular. These themes were soon adopted in early feminist writings, such as Dorothy Smith's Feminism and Marxism, and in feminist revisionist histories such as Mary Jo Deegan's Jane Addams and the Men of the Chicago School, and The Women Founders, by Patricia Madoo Lengermann and Gillian Niebrugge. They later appeared in the black feminist works of Patricia Hill Collins that framed race, class and gender as intersecting systems of oppression. In the Marxist and neo-Marxist approach, however, "culture" was not a key concept. The central focus, rather, was on processes of domination and resistance, with revolution as an ideal. Marx, famously, had asserted that "material factors," especially the economic relations of production, were the driving forces of history, not "ideal factors" such as the components of culture. In recent years, this has been articulated by former ASA president Joe Feagin, Vera Herman and Kimberly Ducey as "liberation sociology."

Given this background and intellectual context, it is perhaps surprising that I became interested in culture. The main reason for this intellectual shift was my reading of Pitirim A. Sorokin's major work, Social and Cultural Dynamics (1937-1941), an epic in four volumes, each of which was nearly a thousand pages long. Sorokin began by posing the issue of the integration of cultural elements and fluctuations of major systems of culture over historical epochs, including periods of emergence, dominance, decline and disintegration. The first volume presented an historical sociology of art, something entirely absent from my training. I found myself wondering, "You can do this in sociology?" (Europeans, of course, would not have been surprised.) Sorokin 
favored the term "sociocultural," which was not widely used in contemporary US discourse. Dynamics seemed to contain everything I had encountered in other approaches: formal processes of association and dissociation; conflict, cooperation and adaptation; stability and change; social psychology. Sorokin called his approach "integral," or holistic. And "culture" held a place of honor in that paradigm. Sorokin did not allege that culture was always good, nor that it always emerged from cooperation. Indeed, he was very clear that particular systems of culture were often imposed against the wishes of those subjected to them. His view of long-term change was dialecticalnot so much in the Hegelian-Marxist-Germanic sense of the clash of opposites as in the more Eastern or Asiatic-Confucian sense of the complementarity of opposites. Before Immanuel Wallerstein developed his "world systems theory," Sorokin was already "global," calling for a broadly international integral culture that blended the strengths of East and West. At Harvard he had bewildered undergraduates read Arnold Toynbee's massive Study of History that covered the rise and fall of numerous civilizations over many centuries, and he lectured on comparable works by Oswald Spengler, Nikolai Danilevsky and Nikolai Berdyaev — all largely unknown in US sociology.

Why I was so moved by Sorokin's approach when the great majority of others in the field were not (and of course most were not exposed to it) is, at least for me, an interesting question. Part of the answer may be that Sorokin's integralism is in some respects very much in accord with the approach I learned in the Catholic world, most fully epitomized in Thomas Aquinas's Summa Theologica that recognizes diverse channels of knowledge or revelation, including the sensory, the intellectual and the spiritual. The Catholic world was also hierarchical (with ordained clergy at the pinnacle) and it accepted the legitimacy of hierarchies (though not all), while also teaching the principle of subsidiarity (i.e., relative autonomy of various levels). This may have influenced me against embracing the notion of class warfare or total equality as a moral absolute. Also, while the church featured social justice teachings (e.g., support for workers and labor unions), it strongly opposed state socialism, especially the militant atheist variety in the Soviet Union. Such catechetics probably also influenced my viewpoint. Whatever the reasons, I was drawn to integralism rather than to what seemed the more limited, and more negativistic, perspective of conflict theory.

Sorokin himself acknowledged that his formulation of integralism was but a "creative variation" on an ancient theme, one that had been manifested in Eastern traditions (Hinduism, Buddhism), as well as in Aristotle, Aquinas and many others over the centuries. I have become an advocate of integralism, and I continue to believe that it can do much to heal divisions within sociology (especially what I have termed an "enemies mentality") and provide a direction for the further development of the field. One particular way, as Sorokin also urged, would be to concentrate more on positive and pro-social phenomena, such as altruism and solidarity and morality (the foci of a recently created section of ASA). We could develop a sociology of love and, going beyond what Sorokin said, though he implied it, do sociology "with love." I am pleased that other colleagues, including Vincent Jeffries, Ed Tiryakian, Jay Weinstein, Samuel Oliner, Matthew Lee, Stephen Post, and Lissa Yogan have provided creative leadership in this effort. Meanwhile, others such as Inge Bell and Janine Schipper have promoted the complementary project of a "Buddhist sociology" that is based on the ideal of compassion. For, with all respect to justice, which many sociologists and sociology departments seem to believe is the guiding value of the field, and which in Catholic 
teaching is among the primary virtues, love remains our greatest ideal. Its virtual absence in sociology (beginning with the vocabulary of introductory textbooks) is sad, and also ironic, given the celebration of love in Auguste Comte's foundational writings. Hate crime, inequality, oppression, violence against women, racism, sexism, homophobia, ageism, ableism, white privilege, etc., are staples in contemporary sociological curricula. But love-centered courses such as Matthew Lee's at the University of Akron or Samuel Oliner's at Humboldt state, remain rare. Why not study the sociology of friendship, reconciliation and forgiveness, peace making, philanthropy, volunteerism, ethical business practice or communitarian relations along the lines of Amitai Etzioni's work? And why not develop, as Vincent Jeffries has advocated, a "sociology of the good"? At some point, there must be a dialectical balance.

In closing, let me express the hope that readers will enjoy this issue of our journal and find it nurturing. I celebrate the "return of culture" to our field and our vocabulary. Indeed, it has become a major event and the recently established section of ASA on culture has quickly grown into one of the largest. There are now culture journals as well as "handbooks," and scholars such as Jeffrey Alexander have become prominent due to work in this area. We can expect this trend, this "cultural turn" to continue. Sorokin, who saw himself as a pathfinder, would very likely feel vindicated. 